Jurnal Ekonomi, Bisnis, dan Akuntansi (JEBA) Volume 21 Nomor 02 Tahun 2019

\title{
PENGARUH SELF EFFICACY DAN EMOTIONAL INTELLIGENCE PEMIMPIN PEREMPUAN TERHADAP KEPUASAN KERJA PEGAWAI DENGAN LEADER MEMBER EXCHANGE (LMX) SEBAGAI VARIABEL PEMEDIASI
}

\author{
Memey Meirita Handayani* \\ Magister Manajemen, Fakultas Ekonomi dan Bisnis, Universitas Trilogi Jakarta* \\ Email Corresponding Author : m3y.m3h4@gmail.com
}

\begin{abstract}
Abstrak
Peranan pemimpin perempuan pada sektor pemerintahan saat ini semakin berkembang, termasuk Kementerian Ketenagakerjan Republik Indonesia. Pemimpin perempuan biasanya digambarkan sebagai sosok yang memperlihatkan sifat-sifat kehangatan dalam hubungan personal dan lebih suka berafiliasi dengan orang lain dan memiliki Ikatan emosional yang lebih dibandingkan dengan pemimpin laki-laki. Pemimpin lakilaki biasanya unggul dalam berfikir dan menganalisis.Sementara perempuan lebih menggunakan perasaan dalam menyelesaikan permasalahan. Dengan pekerjaan rutinitas pada sektor pemerintahan yang berkutat pada sistem birokrasi dan administrasi, maka peneliti mencoba untuk mengetahui kemampuan pemimpin perempuan dalam suatu organisasi dalam melakukan pengelolaan emosionalnya dalam kualitas hubungan antara pemimpin dan bawahan langsung, sehingga bisa memberikan sentuhan yang berbeda pada lingkungan pemerintahan ketika seorang perempuan memimpin suatu organisasi melalui ikatan emosional yang difokuskan pada self efficacy dan emotional intelligence.Tujuan dari penelitian ini adalah untuk mengetahui pengaruh self efficacy dan emotional intelligence pemimpin perempuan terhadap job satisfaction pegawai dengan Leader Member Exchange (LMX) sebagai variabel pemediasi pada Kementerian Ketenagakerjaan Republik Indonesia.Berdasarkan karakteristik masalah yang ada, maka penelitian ini dilakukan menggunakan pendekatan penelitian kuantitatif dengan jumlah partisipan sebanyak 83 orang dan metode analisis menggunakan SmartPLS. Hasil penelitian menunjukkan bahwa terdapat pengaruh yang signifikan antara self efficacy dan emotional pemimpin perempuan terhadap job satisfaction pegawai dengan Leader Member Exchange (LMX) sebagai variabel pemediasi.

Kata Kunci : Efikasi Diri, Kecerdasan Emosional, Kepuasan Kerja dan LMX
\end{abstract}

\begin{abstract}
The role of female leaders in the government sector is currently growing, including the Ministry of Manpower of the Republic of Indonesia. Female leaders are usually portrayed as figures who have warmth in personal relationships and prefer to be affiliated with others and have more emotional ties than male leaders. Male leaders are very good at thinking and analyzing. While women use more feelings in solving problems. With routine work in the government sector related to the bureaucratic and administrative systems, researchers try to find out the ability of female leaders in an organization to implement emotional management in the quality of Leader Member Exchange (LMX) so that they can give different colors to the government environment, women lead an organization through an emotional bond that focuses on self-efficacy and emotional intelligence. The purpose of this study was to determine the effect of female leader self efficacy and emotional intelligence on employee job satisfaction with Member Exchange Leader (LMX) as a mediating variable in the Ministry of Manpower of the Republic of Indonesia. Based on the characteristics of the existing problems, this study was conducted using a quantitative research approach with 83 participants and analytical methods using SmartPLS. The results showed that there was a significant effect between female self-efficacy and emotional leaders on employee job satisfaction with Exchange Member Leaders (LMX) as a mediating variable.

Keyword: Self Efficacy, Emotional Intelligence, Job Satisfaction, Leader Member Exchange (LMX)
\end{abstract}




\section{PENDAHULUAN}

Pertumbuhan penduduk Indonesia setiap tahun semakin meningkat. Berdasarkan proyeksi pertumbuhan penduduk Badan Perencanaan Pembangunan Nasional, Badan Pusat Statistik dan United Nations Population Fund jumlah penduduk Indonesia mencapai 265 juta jiwa. Dari jumlah tersebut, sebanyak 131,88 juta jiwa berjenis kelamin perempuan. Sedangkan Menurut kelompok umur, jumlah populasi perempuan Indonesia yang berusia 0-19 tahun mencapai 45,31 juta jiwa, berusia 20-64 tahun sebanyak 86,57 juta jiwa dan sisanya, yakni 8,3 juta jiwa berumur lanjut usia (65 tahun ke atas).Pada tahun 2010, selisih keduanya mencapai 1,19 juta jiwa, tapi pada tahun 2035 hanya berkisar 266 ribu jiwa.Hal ini menunjukkan bahwa selisih penduduk perempuan dengan lakilaki semakin menyempit.

Kehadiran para pemimpin perempuan pada bidang pemerintahan di Indonesia setiap tahunnya semakin bertambah dengan jumlah yang masih kurang signifikan. Kementerian Ketenagakerjaan Republik Indonesia merupakan Kementerian yang memiliki tugas mengurusi bidang ketenagakerjaan dalam membantu Presiden untuk menyelenggarakan pemerintahan negara. Dalam melaksanakan tugasnya Kementerian Ketenagakerjaan memiliki jumlah pegawai sebanyak 3.307 orang dengan rincian pegawai yang berjenis kelamin laki-laki sebanyak 1987 orang (60,08\%) dan perempuan sebanyak 1.320 orang (39,92\%). Pejabat struktural sebanyak 642 orang dan jumlah pemimpin perempuan yang menduduki jabatan struktural yaitu 36,45\% (berdasarkan data Biro Organisasi dan Kepegawaian Kemnaker Bulan Agustus 2018). Jumlah pegawai laki-laki lebih banyak daripada perempuan dengan selisih jumlah yang cukup signifikan. Tentunya berdampak terhadap jabatan struktural yang diduduki pemimpin laki-laki dan perempuan di Kementerian Ketenagakerjaan.

Cara pemimpin laki-laki dalam menjaga kualitas hubungan dengan bawahannya akan berbeda dengan pemimpin perempuan. Masing-masing pemimpin memiliki strategi khusus dalam melaksanakan tugasnya sebagai pemimpin. Dalam konteks kepemimpinan suatu organisasi, kualitas Hubungan Pemimpin-Bawahan Langsung (HBPL) atau Leader Member Exchange (LMX) merupakan hal yang krusial untuk membangun kedekatan diantara kedua belah pihak.Pemahaman terhadap Leader Member Exchange tidak hanya pada ikatan fisik, dimana bawahan harus selalu mengikuti instruksi atasan, namun lebih dalam lagi yaitu ikatan interaksi antara karyawan dan Pemimpin. Ikatan interaksi ini menyangkut pada ikatan emosional antara karyawan dan Pemimpin. Selain dari pengetahuan dan latar belakang pendidikan para pemimpin, ikatan emosional merupakan bagian penting dari suatu hubungan dalam berorganisasi (Leonard, 2002:1).Ikatan emosional seorang pemimpin menjadi hal yang cukup penting karena dapat dilihat melalui kepercayaan diri (self confident), harga diri (self esteem) dan penilaian diri (self efficacy) serta kecerdasan emosional (emotional intelligence) seorang pemimpin dalam kualitas hubungannya dengan bawahan sehingga apa yang menjadi tujuan organisasi dapat tercapai dengan baik serta kepuasan kerja pegawai dapat terwujud.

Beberapa contoh studi tentang topik kepemimpinan perempuan yang berhubungan dengan LMX dan kepuasan kerja pegawai, antara lain: 1) Choosing the best (wo)man for the job: The effects of mortality salience, sex, and gender stereotypes on leader evaluations (Crystal L. Hoyt, Stefanie Simon, Lindsey Reid, 2009); 2) An exploration of stereotypical beliefs about leadership styles: Is transformational leadership a route to women's promotion? (Claartje J. Vinkenburg, Marloes L. van Engen, Alice H. Eagly, Mary C. Johannesen-Schmidt, 2011); 3) Does valuing androgyny and femininity lead to a femaleDoes valuing androgyny and femininitylead to a female advantage? The relationship between gender-role, transformational leadership and identification (Ronit Kark, Ronit WaismelManor, Boas Shamir, 2012).Studi tersebut secara spesifik meneliti tentang gaya dan peran kepemimpinan perempuan yang memberikan pengaruh pada organisasi serta pekerjaan-pekerjaan yang sesuai untuk pemimpin perempuan.Studi lain tentang kualitas hubungan pemimpin bawahan 
langsung (Leader Member Exchange - LMX), yaitu 1) The role of affect and affective congruence in perceptions of leaders: an experimental study (Michael J. Newcombe, Neal M. Ashkanasy, 2002); dan 2) In-Role Perceptions Buffer the Negative Impact of Low LMX on Helping and Enhance the Positive Impact of High LMX on Voice(Linn Van Dyne, Jeffrey Joireman, Dishan Kamdar, 2008) bahwa penelitian tersebut terkait dengan bagaimana penilaian terhadap pengaruh pemimpin terhadap bawahan melalui persepsi bawahan baik secara In Role Behavior (IRB) maupun Ex Role Behavior (ERB).

Berdasarkan perkembangan isu kesetaraan gender, dan data-data serta studi penelitian sebelumnya, maka penelitian ini fokus kepada kepemimpinan perempuan pada organisasi pemerintahan di Kementerian Ketenagakerjaan RI. Tujuan dari penelitian ini untuk mengetahui pengaruh self efficacy dan emotional intelligence pemimpin perempuan terhadap kepuasan kerja pegawai pada Kementerian Ketenagakerjaan RI dengan LMX sebagai variabel pemediasi.

\section{TINJAUAN PUSTAKA DAN PERUMUSAN HIPOTESIS}

\section{Kepemimpinan}

Pengertian Kepemimpinan menurutHemphill \& Coon (1995).Kepemimpinan adalah perilaku dari seorang individu yang memimpin aktifitas-aktifitas suatu kelompok kesuatu tujuan yang ingin dicapai bersama (shared goal).Dan menurut George R. Terry (yang dikutip dari Sutarto, 1998:17).Kepemimpinan adalah hubungan yang ada dalam diri seseorang atau pemimpin, mempengaruhi orang lain untuk bekerja secara sadar sedangkan menurut Kartini Kartono (1994:48).Kepemimpinan itu sifatnya spesifik, khas, diperlukan bagi satu situasi khusus. Sebab dalam suatu kelompok yang melakukan aktivitas-aktivitas tertentu, dan mempunyai suatu tujuan serta peralatan-peralatan yang khusus. Pemimpin kelompok dengan ciri-ciri karakteristik itu merupakan fungsi dari situasi khusus.Sedangkan menurut Veithzal Rivai (2004)Kepemimpinan adalah proses mempengaruhi atau memberi contoh dari pemimpin kepada pengikutnya dalam upaya mencapai tujuan organisasi. Menurut Rivai dan Mulyadi (dalam Teguh Sriwidadi dan Oey Charlie, 2011)Kepemimpinan adalah sebagai proses mengarahkan dan memengaruhi aktivitasaktivitas yang ada hubungannya dengan pekerjaan para anggota kelompok.

Dari beberapa definisi di atas dapat disimpulkan bahwa kepemimpinan merupakan kemampuan mempengaruhi orang lain, bawahan atau kelompok, kemampuan mengarahkan tingkah laku bawahan atau kelompok, memiliki kemampuan atau keahlian khusus dalam bidang yang diinginkan oleh kelompoknya, untuk mencapai tujuan organisasi atau kelompok.Beberapa teori telah dikemukakan para ahli manajemen mengenai timbulnya seorang pemimpin. Dalam penelitian ini mempertimbangkan Teori Kepemimpinan Situasional dari Paul Hersey dan Ken Blanchard yaitusetiap pemimpin memiliki gaya yang berbeda-beda tergantung kepada tingkat kesiapan pengikutnya. Menurut teori ini pemimpin yang efektif merupakan pemimpin yang mampu menyesuaikan gaya kepemimpinan terhadap tuntutan situasi yang berubah-ubah. Gaya kepemimpinan yang tepat bergantung pula oleh kesiapan/kematangan individu atau kelompok sebagai pengikut.

\section{Gender}

Caplan (1987) menegaskan bahwa gender merupakan perbedaan perilaku antara laki-laki dan perempuan selain dari struktur biologis, sebagian besar justru terbentuk melalui proses social dan cultural. Gender dalam ilmu sosial diartikan sebagai pola relasi lelaki dan perempuan yang didasarkan pada ciri sosial masing-masing (Zainuddin, 2006:1). Sedangkan menurut Hillary M. Lips mengartikan gender sebagai harapan-harapan budaya terhadap laki-laki dan perempuan (cultural expectations for women and men). Sedangkan Linda L. Lindsey menganggap bahwa semua ketetapan 
masyarakat perihal penentuan seseorang sebagai laki-laki dan perempuan adalah termasuk bidang kajian gender (what a given society defines as masculine or feminim is a component of gender).

Keyakinan yang bias mengenai keterampilan dan perilaku yang diperlukan untuk kepemimpinan yang efektif adalah satu alasan diskriminasi berdasarkan jenis kelamin. Untuk waktu yang lama, perempuan diasumsikan sebagai orang yang tidak mampu dan tidak bersedia menggunakan perilaku maskulin yang dianggap penting untuk kepemimpinan efektif. Tetapi, dampak dari stereotype gender pada evaluasi manajer perempuan terlalu berlebihan. Ketika stereotype gender berubah dari waktu ke waktu dalam populasi umum, stereotype itu mungkin akan menjadi kurang penting sebagai sumber harapan peran yang bias bagi pemimpin. Pada teori keunggulan feminin menegaskan bahwa perempuan lebih peduli dengan pembangunan konsensus, keikutsertaan, dan hubungan antarpribadi.

\section{Self Efficacy dan Emotional Intelligence}

Bandura (2001) mendefinisikan efikasi diri sebagai keyakinan seseorang dalam kempampuannya untuk melakukan suatu bentuk kontrol terhadap keberfungsian orang itu sendiri dan kejadian dalam lingkungan. Bandura beranggapan bahwa keyakinan atas efikasi seseorang adalah landasan dari agen manusia. Manusia yang yakin bahwa mereka dapat melakukan sesuatu yang mempunyai potensi untuk dapat mengubah kejadian di lingkungannya, akan lebih mungkin untuk bertindak dan lebih mungkin untuk menjadi sukses dari pada manusia yang mempunyai efikasi diri yang rendah.

Efikasi diri tidak hanya merupakan konsep global atau yang digeneralisasi, seperti harga diri (SelfEsteem) atau kepercayaan diri (Self Confidence).Orang dapat mempunyai efikasi diri yang tinggi dalam satu situasi dan mempunyai efikasi diri yang rendah dalam situasi lainnya. Efikasi diri bervariasi dari satu situasi ke situasi lain, tergantung pada kompetensi yang dibutuhkan untuk kegiatan yang berbeda; ada atau tidaknya orang lain; kompetensi yang dipersepsikan dari orang lain tersebut, terutama apabila mereka adalah kompetitor; predisposisi dari orang tersebut yang lebih condong terhadap kegagalan atas performa dari pada keberhasilan; kondisi psikologis yang mendampinginya; terutama adanya rasa kelelahan, kecemasan, apatis, dan ketidakberdayaan (Feist: 2010)

Daniel Golemen, dalam bukunya Emotional Intelligence (1994) menyatakan bahwa "kontribusi IQ bagi keberhasilan seseorang hanya sekitar $20 \%$ dan sisanya yang $80 \%$ ditentukan oleh serumpun faktor-faktor yang disebut kecerdasan emosional. Orang yang memiliki kecerdasan emosional yang tinggi akan berupaya menciptakan keseimbangan dalam dirinya; bisa mengusahakan kebahagian dari dalam dirinya sendiri dan bisa mengubah sesuatu yang buruk menjadi sesuatu yang positif dan bermanfaat. Kecerdasan emosional inilah yang mempunyai pengaruh besar dalam kehidupan seseorang.

\section{Leader Member Exchange (LMX)}

Pengertian leader member exchange (LMX) merupakan peningkatan kualitas hubungan antara supervisi dengan karyawan akan mampu meningkatkan kerja keduanya (Morrow,2005:682). Namun realitasnya, hubungan antara karyawan dan supervisi dapat dikelompokkan pada dua hubungan yaitu hubungan yang baik dan hubungan yang buruk. Hubungan yang baik akan menciptakan kepercayaan karyawan, sikap positif, dan loyalitas, namun hubungan yang buruk akan berpengaruh sebaliknya.

Leader Member Exchange difokuskan pada penilaian terhadap hubungan dan interaksi antara supervisor (atasan) dan bawahan (Truckenbrodt, 2000:233). Tingkat kedekatan dari hubungan antara Pemimpin dan bawahan ini yang menunjukkan adanya indikasi dari Leader Member Exchange di perusahaan.Dalam sebuah organisasi, dimungkinkan terdapat hubungan yang 
berbeda antara Pemimpin dengan karyawan yang menjadi anak buahnya. Tingkat kedekatan hubungan ini biasa disebut dengan Leader Member Exchange (Welliam, 2003:1). Teori Leader Member Exchange menempatkan konsep hubungan sebagai dasar penilaian terjadinyaLeader Member Exchange. Dalam lingkungan organisasi, maka Leader Member Exchange ini mengarah padahubungan antara Pemimpin dengan karyawan yang menjadi pengikut Pemimpin.

Berdasarkan definisi di atas, maka dalam penelitian ini yang berkaitan dengan kualitas hubungan pemimpin dan bawahan langsung mempertimbangkan teori yaitu Teori Leader Member Exchange (LMX). Teori tersebut menjelaskan mengenai proses hubungan antara pemimpin dan bawahan yaitu (1) Menilai Bawahan; (2) Pengembangan Kepercayaan; dan (3) Terciptanya ikatan emosional.

\section{Job Satisfaction}

Richard, Robert dan Gordon (2012:312,337) menegaskan bahwa kepuasan kerja berhubungan dengan perasaan atau sikap seseorang mengenai pekerjaan itu sendiri, gaji, kesempatan promosi atau pendidikan, pengawasan, rekan kerja, beban kerja dan lain-lain. Kepuasan kerja seorang pegawai dapat merasakan pekerjaannya apakah menyenangkan atau tidak menyenangkan untuk dikerjakan (Wilson Bangun, 2012:327). Kepuasan kerja adalah keadaan emosional yang menyenangkan atau tidak menyenangkan terhadap pekerjaan, kepuasan kerja mencerminkan perasaan seeorang terhadap terhadap pekerjaannya (Dadang (2013:15). Menurut Edy Sutrisno (2014:73) kepuasan kerja menjadi masalah yang cukup menarik dan penting, karena terbukti besar manfaatnya bagi kepentingan individu, industri dan masyarakat. Bagi individu, penelitian tentang sebab-sebab dan sumber-sumber kepuasan kerja memungkinkan timbulnya usaha-usaha peningkatan kebahagiaan hidup mereka. Bagi industri, penelitian mengenai kepuasan kerja dilakukan dalam rangka usaha peningkatan produksi dan pengaruh biaya melalui perbaikan sikap dan tingkah laku karyawannya. Selanjutnya, masyarakat tentu akan menikmati hasil kapasitas maksimum dari industri serta naiknya nilai manusia di dalam konteks pekerjaan.

Dari berbagai pendapat di atas dapat disimpulkan bahwa faktor-faktor yang mempengaruhi kepuasan kerja, yaitu; (1) Faktor Psikologis, merupakan faktor yang berhubungan dengan kejiwaan, yang meliputi minat, ketentraman dalam kerja, sikap terhadap kerja, bakat dan keterampilan; (2) Faktor Sosial, merupakan faktor yang berhubungan dengan interaksi soasil antar karyawan maupun karyawan dengan atasan; (3) Faktor Fisik, merupakan faktor yang berhubungan dengan kondisi fisik karyawa, meliputi jenis pekerjaan, pengaturan waktu dan waktu istirahat, perlengkapan kerja, keadaan karyawan, umur, dan sebagainya; dan (4) Faktor Finansial, merupakan faktor yang berhubungan dengan jaminan serta kesejahteraan karyawan, yang meliput sistem dan besarnya gaji, jaminan sosial, macam-macam tunjangan, fasilitas yang diberikan, promosi dan sebagainya 


\section{KERANGKA PEMIKIRAN DAN HIPOTESIS}

Kerangka pemikiran dalam penelitian ini merupakan replikasi dan pengembangan dari beberapa penelitian sebelumnya yang menemukan bahwa self Efficacy dan Emotional Intelligence berpengaruh positif pada Job Satisfaction dengan menambahkan Leader Member Exchange (LMX) sebagai variabel pemediasi dan penelitian ini difokuskan kepada pemimpin perempuan sebagai atasan langsung.

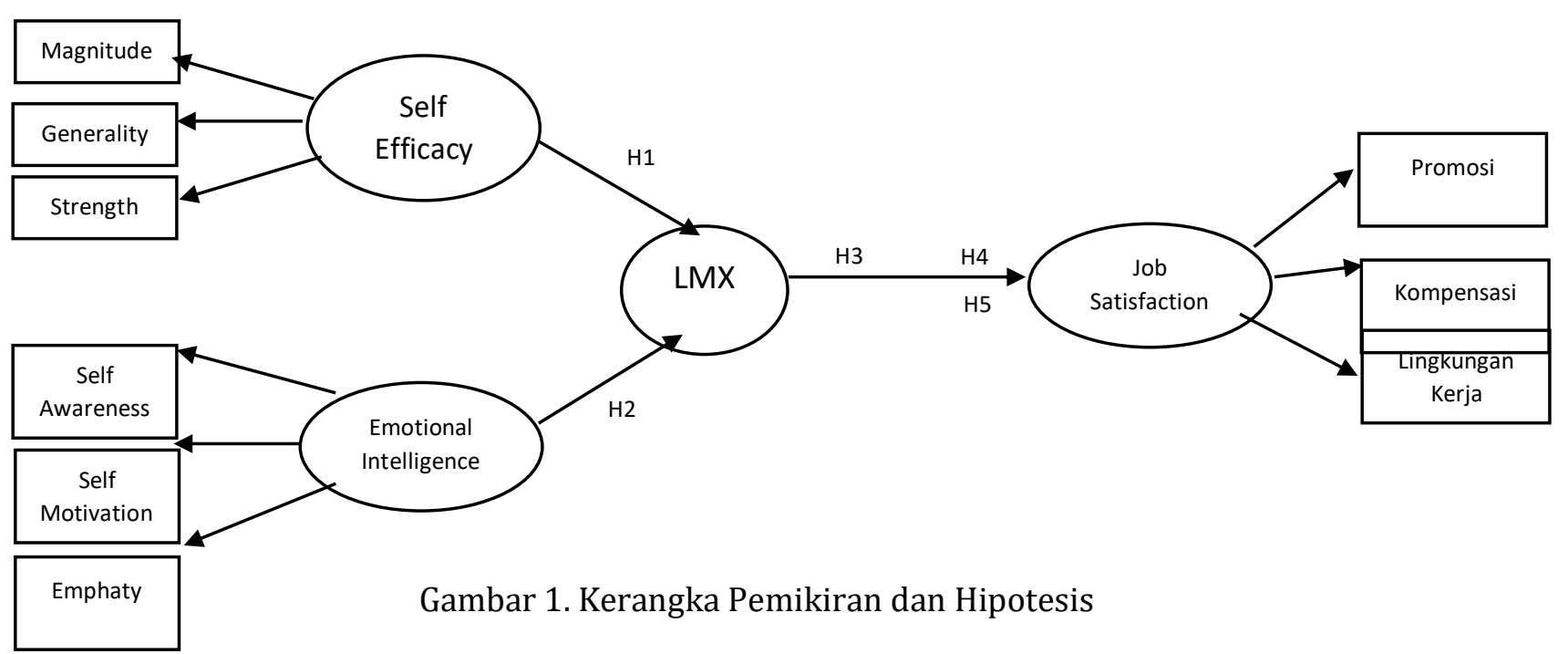

Hipotesis 1 (H1): Self Efficacy pemimpin perempuan memiliki pengaruh positif terhadap Leader Member Exchange ( $L M X)$ pada Kementerian Ketenagakerjaan

Hipotesis 2 (H2) : Emotional Intelligence pemimpin perempuan memiliki pengaruh positif terhadap Leader Member Exchange pada Kementerian Ketenagakerjaan

Hipotesis 3 (H3) : Leader Member Exchange (LMX) pemimpin perempuan memiliki pengaruh positif terhadap Job Satisfaction Pegawai pada Kementerian Ketenagakerjaan

Hipotesis 4 (H4) : Self Efficacy pemimpin perempuan memiliki pengaruh positif terhadap Job satisfaction pegawai pada Kementerian Ketenagakerjaan dengan Leader Member Exchange (LMX) sebagai variabel pemediasi.

Hipotesis 5 (H5) : Emotional Intelligence pemimpin perempuan memiliki pengaruh positif terhadap Job Satisfaction Pegawai pada Kementerian Ketenagakerjaan dengan Leader Member Exchange ( $L M X)$ sebagai variabel pemediasi.

\section{METODE PENELITIAN}

Berdasarkan karakteristik masalah yang ada, maka penelitian ini dilakukan dengan pendekatan penelitian kuantitatif. Data yang digunakan dalam penelitian ini ada 2 (dua) yaitu data primer dan data sekunder. Data primer adalah data yang dicari langsung oleh peneliti pada saat penelitian di lapangan. Sedangkan untuk data sekunder diperoleh dari data yang tersedia di Kementerian Ketenagakerjaan berupa jumlah pegawai dan jumlah pejabat struktural di Kementerian Ketenagakerjaan tahun 2018.Populasi yang digunakan adalah pegawai di Kementerian Ketenagakerjaan yang memiliki pemimpin langsung perempuan. Jumlah populasi yang ada yang akan dilakukan untuk penelitian adalah sebanyak 464 orang dengan kriteria masing-masing pemimpin memiliki bawahan langsung sebanyak 2 orang. Teknik pengambilan sampel dalam penelitian ini menggunakan metode non probability sampling dengan teknik purposive sampling. 
Berdasarkan hasil perhitungan rumus slovin, maka diperoleh sampel sebanyak 83 orang dan responden yang dipilih adalah yang berusia berkisar 25 tahun s.d. 58 tahun yang telah bekerja minimal 1 (satu) tahun.

Penyusunan instrumen dalam penelitian ini berasal dari penelitian sebelumnya yang mengadopsi jurnal internasional dan disesuaikan dengan judul penelitian. Skala pengukuran penelitian ini menggunakan Skala Likert 1-5 (1=sangat tidak setuju; 2=tidak setuju; 3=cukup; 4=setuju; 5= sangat setuju). Metode pengumpulan data dilakukan dengan metode pengisian angket dengan waktu pengumpulan data dilakukan selama 2 (dua) bulan yaitu Bulan Januari s.d Februari 2019. Sedangkan untuk menguji hipotesis hubungan antar variabel digunakan alat analisis SmartPLS.

\section{HASIL DAN PEMBAHASAN}

\section{Deskripsi Responden}

Populasi dalam penelitian ini adalah pegawai yang berada di bawah kepemimpinan perempuan di lingkungan Kementerian Ketenagakerjaan Republik Indonesia. Sampel dalam penelitian ini berdasarkan hasil perhitungan dengan menggunakan rumus Slovin adalah sebanyak 83 pegawai yang berada di bawah kepemimpinan perempuan di lingkungan Kementerian Ketenagakerjaan Republik Indonesia. Instrument yang digunakan dalam penelitian ini berupa kuesioner yang diberikan langsung kepada responden di setiap satuan kerja yang menjadi tempat penelitian. Kuesioner diedarkan pada tanggal 7 Januari sampai dengan 7 Februari 2019. Total kuesioner yang disebarkan dalam penelitian ini berjumlah 83 kuesioner. Dari 83 kuesioner yang disebarkan, diterima kembali sebanyak $100 \%$.

Tabel 1. Profil Responden Penelitian

\begin{tabular}{|c|c|c|}
\hline Uraian & Frekuensi & Presentase \\
\hline \multicolumn{3}{|l|}{ Jenis Kelamin : } \\
\hline 1. Perempuan & 40 & $48,20 \%$ \\
\hline 2. Laki-Laki & 43 & $51,80 \%$ \\
\hline Jumlah & 83 & $100 \%$ \\
\hline \multicolumn{3}{|l|}{ Usia : } \\
\hline 1. $<25$ tahun & 8 & $9,64 \%$ \\
\hline 2. $26-35$ tahun & 36 & $43,37 \%$ \\
\hline 3. $36-45$ tahun & 22 & $26,51 \%$ \\
\hline 4. $46-55$ tahun & 16 & $19,28 \%$ \\
\hline 5. $>55$ tahun & 1 & $1,20 \%$ \\
\hline Jumlah & 83 & $100 \%$ \\
\hline \multicolumn{3}{|l|}{ Pendidikan : } \\
\hline 1. SMA/SMEA/SMK & 14 & $16,87 \%$ \\
\hline 2. D3 & 10 & $12,05 \%$ \\
\hline 3. $\mathrm{D} 4$ & 1 & $1,20 \%$ \\
\hline 4. $\mathrm{S} 1$ & 42 & $50,60 \%$ \\
\hline 5. S2 & 16 & $19,28 \%$ \\
\hline Jumlah & 187 & $100 \%$ \\
\hline \multicolumn{3}{|l|}{ Unit Kerja : } \\
\hline 1. Sekretariat Jenderal & 38 & $45,79 \%$ \\
\hline 2. Ditjen Pembinaan Pelatihan dan Produktivitas & 17 & $20,48 \%$ \\
\hline $\begin{array}{l}\text { 3. Ditjen Pembinaan Penempatan Tenaga Kerja dan } \\
\text { Perluasan Kesempatan Kerja }\end{array}$ & 0 & $0 \%$ \\
\hline $\begin{array}{l}\text { 4. Ditjen Pembinaan Hubungan Industrial dan Jaminan Sosial } \\
\text { Tenaga Kerja }\end{array}$ & 8 & $9,64 \%$ \\
\hline 5. DitjenPembinaan Pengawasan Ketenagakerjaan dan & 9 & $10,84 \%$ \\
\hline
\end{tabular}




\begin{tabular}{rlrr} 
6eselamatan dan Kesehatan Kerja & & \\
6. & Inspektorat Jenderal & 0 & $0 \%$ \\
7. & Badan Perencanaan dan Pengembangan Ketenagakerjaan & 11 & $13,25 \%$ \\
\hline \multicolumn{2}{l}{ Jumlah } & $\mathbf{8 3}$ & $\mathbf{1 0 0 \%}$ \\
\hline Masa Kerja: & & \\
$1 . \quad<10$ tahun & 26 & $31,33 \%$ \\
2. & $11-20$ tahun & 22 & $26,51 \%$ \\
3. & $21-30$ tahun & 19 & $22,90 \%$ \\
$4 . \quad>31$ tahun & 16 & $19,26 \%$ \\
\hline \multicolumn{2}{r}{} & $\mathbf{8 3}$ & $\mathbf{1 0 0 \%}$ \\
\hline
\end{tabular}

Sumber : Data primer diolah, 2019

Sesuai dengan kerangka pemikiran dan hipotesis yang dituangkan pada Gambar 1., kelima hipotesis di atas dapat disajikan menjadi sebuah diagram jalur seperti tersaji pada Gambar 2. diagram jalur inilah yang telah dilakukan analisis menggunakan SmartPLS.

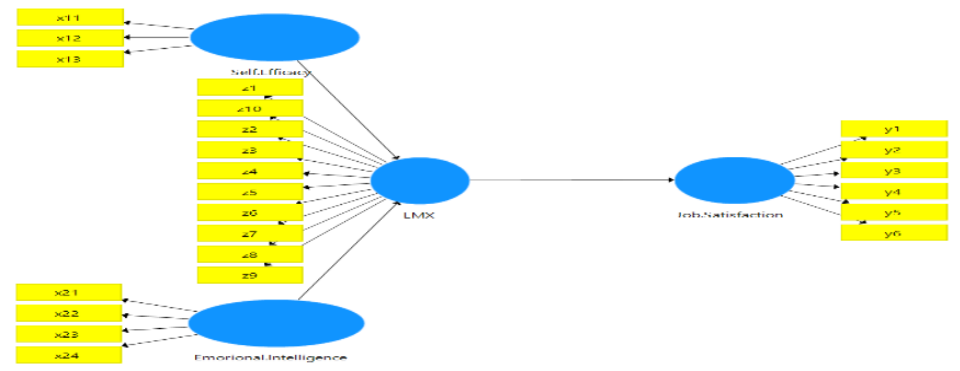

Gambar 2. Diagram Jalur Hipotesis menggunakan SmartPLS

Adapun analisa pada SmartPLS dianalisis melalui (1) Analisa Outer model dan (2) Analisa Inner Model. Adapun analisa outer model adalah untuk menspesifikasikan hubungan antara varaiabel laten dengan indikator-indikatornya atau dengan kata lain outer model mendefinisikan bagaimana setiap indikator berhubungan dengan variabel latennya. Berikut beberapa uji validitas dan reliabilitas yang dilakukan dalam analisa outer model penelitian ini yaitu (1) Convergent Validity; (2) Discriminant Validity; dan (3) Composite Reliability, Average Variage Extracted, Cronbach's Alpha.

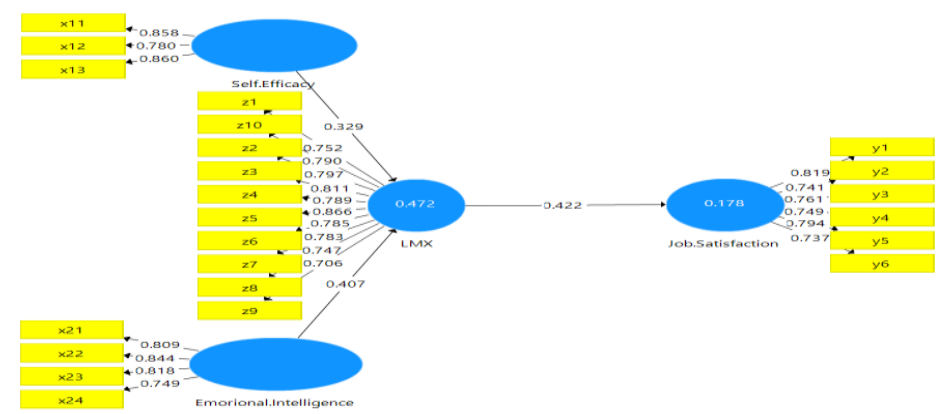

Gambar 3. Tampilan Hasil PLS Algorithm

Dalam penelitian ini ada 4 konstruk dengan jumlah indikator 3-10 dengan skala 1-5. Berdasarkan hasil pengujian model pengukuran yangterlihat pada gambar 3 dapat dijelaskan sebagai berikut:

a. Konstruk Self Efficacy pemimpin perempuan diukur dengan menggunakan dimensi magnitude, generality dan strength yang berisi variabel x11 $(0,858), \mathrm{x} 12(0,780)$ dan $\mathrm{x} 13(0,860)$ sehingga indikator memiliki loading factor di atas 0,7. 
b. Konstruk Emotional Intelligence pemimpin perempuan diukur dengan menggunakan dimensi self awareness, self motivation,emphatyyang berisi variabel x21(0,809), x $22(0,844), \mathrm{x} 23(0,818)$ dan x24(0,749) sehingga indikator memiliki loading factor di atas 0,7.

c. Konstruk Leader Member Exchange pemimpin perempuan diukur dengan menggunakan dimensi afeksi, loyalitas,kontribusi, penghormatan profesional yang berisi variabel $\mathrm{z} 1(0,752)$, z2(0,797), z3(0,811), z4(0,789), z5(0,866), z6(0,785), z7(0,783), z8(0,747), z9(0,706), z10 $(0,790)$ sehingga indikator memiliki loading factor di atas 0,7 .

d. Konstruk Job Satisfaction pegawai diukur dengan menggunakan dimensi promosi,kompensasi, dan lingkungan kerja yang berisi variabel y1(0,819), y2 $(0,741), y 3(0,761), y 4(0,749)$, y5 $(0,794)$, dan y6 $(0,737)$ sehingga indikator memiliki loading factor di atas 0,7 .

Berdasarkan tampilan hasil PLS Algorithm diperoleh bahwa indikator-indikator tersebut merupakan indikator yang valid untuk mengukur konstruknya.

Nilai Discriminant Validity merupakan nilai cross loading faktor yang berguna untuk mengetahui apakah konstruk dalam penelitian ini memiliki diskriminan yang memadai yaitu dengan cara membandingkan nilai loading pada konstruk yang dituju harus lebih besar dibandingkan dengan nilai loading dari konstruk yang lain. Berdasarkan gambat di atas, menunjukkan adanya discriminate validity yang baik oleh karena nilai korelasi indikator terhadap konstruknya lebih tinggi dibandingkan nilai korelasi indikator terhadap konstruknya lebih tinggi dibandingkan nilai korelasi indikator dengan konstruk lainnya.

Tabel 2. Discriminant Validity

\begin{tabular}{|c|c|c|c|c|}
\hline Konstruk & (X1) & $(\mathrm{X} 2)$ & $(\mathrm{Z})$ & $(\mathrm{Y})$ \\
\hline $\begin{array}{l}\text { 1. Self Efficacy } \\
\text { perempuan (X1) }\end{array}$ & 0,834 & & & \\
\hline $\begin{array}{l}\text { 2. Emotional Intelligence } \\
\text { pemimpin perempuan (X2) }\end{array}$ & 0,739 & 0,806 & & \\
\hline 3. Leader Member Exchange (Z) & 0,630 & 0,650 & 0,784 & \\
\hline 4. Job Satisfaction pegawai (Y) & 0,223 & 0,254 & 0,422 & 0,767 \\
\hline
\end{tabular}

Sumber: Pengolahan Data PLS, 2019

Disamping uji validitas konstruk, dilakukan juga uji reliabilitas konstruk yang diukur dengan composite reliability, average variance extracted (AVE), dan cronbach's alpha. Data yang memiliki composite reliability > 0,7 mempunyai reliabilitas yang tinggi. Untuk nilai AVE yang diharapkan adalah $>0,5$ serta nilai yang diharapkan dalam cronbach's alpha adalah $>0,7$. Berikut adalah hasil pengujian composite reliability,average variance extracted (AVE), dan cronbach's alpha dari SmartPLS:

Tabel 3. Composite Reliability, Average Variance Extracted, Cronbach's Alpha

\begin{tabular}{llllll}
\hline Konstruk & $\begin{array}{l}\text { Composite } \\
\text { Reliability }\end{array}$ & AVE & $\begin{array}{l}\text { Cronbach's } \\
\text { Alpha }\end{array}$ & Rho_A \\
\hline 1. & $\begin{array}{l}\text { Self Efficacy pemimpin } \\
\text { perempuan (X1) }\end{array}$ & 0,872 & 0,695 & 0,782 & 0,798 \\
2. Intelligence & 0,881 & 0,650 & 0,821 & 0,833 \\
$\begin{array}{l}\text { Emotional pemimpin perempuan (X2) } \\
\text { 3. }\end{array}$ & $\begin{array}{l}\text { Leader Member Exchange } \\
\text { (Z) }\end{array}$ & 0,941 & 0,614 & 0,930 & 0,931 \\
4. & Job Satisfaction pegawai (Y) & 0,896 & 0,589 & 0,867 & 0,910 \\
\hline
\end{tabular}

Sumber: Pengolahan Data PLS, 2019

Analisa inner model / analisa model struktural dilakukan utnuk memastikan bahwa model struktural yang dibangun adalah akurat. Evaluasi inner model dapat dilihat dari beberapa 
indikator yaitu Koefisien Determinasi $\left(\mathrm{R}^{2}\right)$, Predictive Relevance $\left(\mathrm{Q}^{2}\right)$, dan Goodness of Fit Index (GoF).

Tabel 4. Koefisien Determinasi ( $\left.\mathbf{R}^{2}\right)$.

\begin{tabular}{|c|c|c|}
\hline Konstruk & $\mathbf{R}^{\mathbf{2}}$ & $\mathbf{R}^{\mathbf{2}}$ Adjusted \\
\hline LMX (Z) & 0,472 & 0,458 \\
Job Satisfaction (Y) & 0,178 & 0,168 \\
\hline
\end{tabular}

Untuk menghitung Predictive Relevance $\mathrm{Q}^{2}$ menggunakan rumus sebagai berikut :

$\mathrm{Q}^{2}: 1-\left(1-\mathrm{R} 1^{2}\right)\left(1-\mathrm{R} 2^{2}\right)$

$\mathrm{Q}^{2}: 1-\left(1-0,472^{2}\right)\left(1-0,178^{2}\right)$.

$\mathrm{Q}^{2}: 1-(0,777)(0,968)$

$\mathrm{Q}^{2}: 1-0,752$

$\mathrm{Q}^{2}: 0,248$

Goodness of Fit (GoF) diukur menggunakan R-square variabel laten dependen dengan interpretasi yang sama dengan regresi. Q-square predictive relevance untuk model struktural, mengukur seberapa baik nilai observasi dihasilkan oleh model dan juga estimasi parameternya. Nilai Q-square >0 menunjukkan model memiliki predictive relevance sebaliknya jika nilai Q-square $\leq$ 0 menunjukkan model kurang memiliki predictive relavance. Berdasarkan data dan perhitungan yang ada, maka diperoleh nilai Q-square sebesar 0,248 sehingga untuk model struktur ini menunjukkan bahwa Nilai Q-square > 0 , dapat disimpulkan bahwa model memiliki predictive relevance yang baik.Model struktural PLS dievaluasi dengan menggunakan $\mathrm{R}^{2}$ untuk variabel dependen dan nilai koefisien path untuk varabel independen yang kemudian dinilai signifikansinya berdasarkan nilai t-statistic setiap path. Adapun model struktural penelitian ini dapat dilihat pada gambar sebagai berikut :

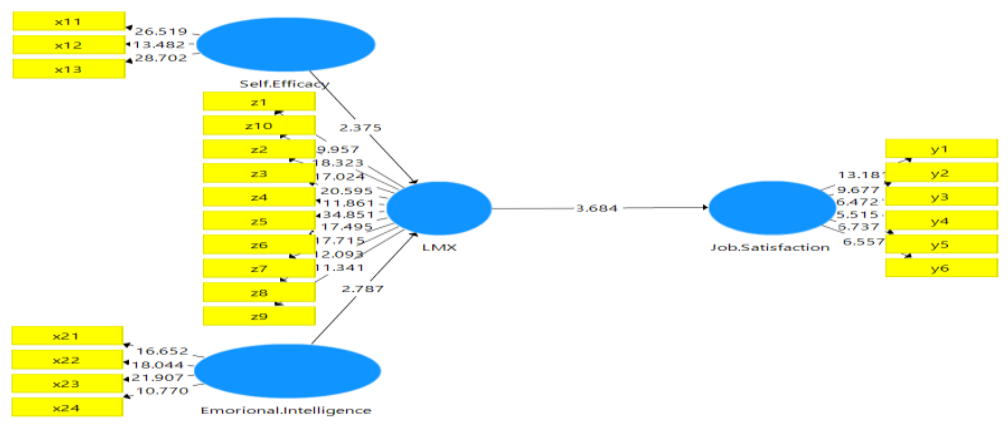

Gambar 4. Tampilan Hasil PLS Bootstrapping

Untuk menilai signifikansi model prediksi dalam pengujian model struktural, dapat dilihat dari nilai $t$-statistic antara variable independen ke variable dependen dalam table Path Coefficient pada output SmartPLS di bawah ini :

Tabel 5. Path Coefficient (Mean, STDev, T-Value)

\begin{tabular}{|l|c|c|c|c|c|c|}
\hline & $\begin{array}{c}\text { Original } \\
\text { Sample (O) }\end{array}$ & $\begin{array}{c}\text { Sample } \\
\text { Mean (M) }\end{array}$ & $\begin{array}{c}\text { Standard } \\
\text { Deviation } \\
\text { (STDEV) }\end{array}$ & T-Statistic & P-Values & Signifikansi \\
\hline $\begin{array}{l}\text { Self Efficacy pemimpin } \\
\text { perempuan (X1) -> } \\
\text { Leaader Member } \\
\text { Exchange (LMX) (Z) }\end{array}$ & 0,329 & 0,333 & 0,138 & 2,375 & 0,018 & Signifikan \\
\hline $\begin{array}{l}\text { Leader Member } \\
\text { Exchange (LMX) (Z)-> } \\
\text { Job Satisfaction (Y) }\end{array}$ & 0,422 & 0,448 & 0,114 & 3,684 & 0,000 & Signifikan \\
\hline Emotional Intelligence & & & & & & \\
\hline
\end{tabular}




\begin{tabular}{|c|c|c|c|c|c|c|}
\hline $\begin{array}{lr}\text { pemimpin } & \text { perempuan } \\
(\mathrm{X} 2) \quad \rightarrow & \text { Leader } \\
\text { Member } & \text { Exchange } \\
(\mathrm{LMX})(\mathrm{Z}) & \\
\end{array}$ & 0,407 & 0,412 & 0,146 & 2,787 & 0,006 & Signifikan \\
\hline
\end{tabular}

Sumber : Pengolahan Data PLS, 2019

Dalam uji t dimaksudkan untuk menguji apakah variable independen secara parsial berpengaruh signifikan terhadap variable dependen ( $\mathrm{t}$-tabel untuk alfa $=0,05$ adalah 1,96 dan $\mathrm{t}$ table untuk alfa 0,10 adalah 1,65, dengan hipotesis sebagai berikut :

\section{Pengujian Hipotesis 1 (H1)}

Hipotesis 1 (H1): Self Efficacy pemimpin perempuan memiliki pengaruh positif terhadap Leader Member Exchange (LMX) pada Kementerian Ketenagakerjaan.

H0: variable $\mathrm{x} 1$ tidak berpengaruh secara signifikan terhadap variabel z

H1:variable $\mathrm{x} 1$ berpengaruh secara signifikan terhadap variabel z

Dasar dari pengambilan keputusan tersebut adalah:

a. Jika probabilitasnya $>0.05$ atau -t-tabel $<\mathrm{t}$ hitung $<\mathrm{t}$ table, maka $\mathrm{H} 0$ tidak ditolak.

b. Jika probabilitasnya $<0.05$ atau t-hitung $<-$ t table atau t-hitung $>$ t-tabel, maka H0 ditolak

Dari tabel 5. di atas dapat dilihat nilai $P$-Values 0,018 di bawah 0,05 yang ditunjukkan dengan nilai tStatistic 2,375 lebih besar dari nilai t-tabel sebesar 1,96. Berdasarkan perhitungan tersebut, maka pengaruh Self Efficacy Pemimpin Perempuan (X1) terhadap Leader Member Exchange (Z) mengindikasikan bahwa H0 ditolak, yang berarti variabel self efficacy pemimpin perempuan (X1) memiliki pengaruh signifikan terhadap variabel Leader Member Exchange (z). Berdasarkan hasil tersebut disimpulkan hipotesis pertama diterima bahwa Self Efficacy pemimpin perempuan memiliki pengaruh positif terhadap Leader Member Exchange (Z) pada Kementerian Ketenagakerjaan.

\section{Pengujian Hipotesis 2 (H2)}

Hipotesis 2 (H2): Leader Member Exchange (LMX) pemimpin perempuan dan bawahan memiliki pengaruh positif terhadap Job Satisfaction Pegawai pada Kementerian Ketenagakerjaan.

H0: variable z tidak berpengaruh secara signifikan terhadap variabel y

H1: variable $\mathrm{z}$ berpengaruh secara signifikan terhadap variabel y

Dasar dari pengambilan keputusan tersebut adalah:

a. Jika probabilitasnya $>0.05$ atau $-\mathrm{t}$-tabel $<\mathrm{t}$ hitung $<\mathrm{t}$ table, maka $\mathrm{H} 0$ tidak ditolak.

b. Jika probabilitasnya $<0.05$ atau t-hitung $<-\mathrm{t}$ table atau $\mathrm{t}$-hitung $>\mathrm{t}$-tabel, maka $\mathrm{HO}$ ditolak

Dari tabel 5.5. di atas dapat dilihat nilai P-Values 0.000 di bawah 0,05 yang ditunjukkan dengan nilai t-Statistic 3,684 lebih besar dari nilai t-tabel sebesar 1,96. Berdasarkan perhitungan tersebut, maka Leader Member Exchange (Z) terhadap Job Satisfaction (Y) mengindikasikan bahwa H0 ditolak, yang berarti variabel Leader Member Exchange (Z) memiliki pengaruh signifikan terhadap variabel Job Satisfaction (Y). Berdasarkan hasil tersebut disimpulkan hipotesis kedua diterima bahwa Leader Member Exchange (LMX) pemimpin perempuan dan bawahan memiliki pengaruh positif terhadap Job Satisfaction Pegawai pada Kementerian Ketenagakerjaan.

\section{Pengujian Hipotesis 3 (H3)}

Hipotesis 3 (H3) : Emotional Intelligence pemimpin perempuan memiliki pengaruh positif terhadap Leader Member Exchange pada Kementerian Ketenagakerjaan.

H0: variable $\mathrm{x} 2$ tidak berpengaruh secara signifikan terhadap variabel z 
H1: variable x2 berpengaruh secara signifikan terhadap variabel z

Dasar dari pengambilan keputusan tersebut adalah:

Jika probabilitasnya $>0.05$ atau $-\mathrm{t}$-tabel $<\mathrm{t}$ hitung $<\mathrm{t}$ table, maka $\mathrm{H} 0$ tidak ditolak.

Jika probabilitasnya $<0.05$ atau t-hitung $<$-t table atau t-hitung $>$ t-tabel, maka H0 ditolak

Dari tabel 5. di atas dapat dilihat nilai $P$-Values 0.006 di bawah 0,05 yang ditunjukkan dengan nilai tStatistic 2,782 lebih besar dari nilai t-tabel sebesar 1,96. Berdasarkan perhitungan tersebut, maka pengaruh Emotional Intelligence Pemimpin Perempuan (X2) terhadap Leader Member Exchange (Z) mengindikasikan bahwa HO ditolak, yang berarti variabel Emotional Intelligence pemimpin perempuan (X2) memiliki pengaruh signifikan terhadap variabel Leader Member Exchange (Z). Berdasarkan hasil tersebut disimpulkan hipotesis ketiga diterima bahwa Emotional Intelligence pemimpin perempuan memiliki pengaruh positif terhadap Leader Member Exchange (Z) pada Kementerian Ketenagakerjaan

\section{Pengujian Hipotesis 4 (H4)}

Hipotesis 4 (H4) : Self Efficacy pemimpin perempuan memiliki pengaruh positif terhadap Job satisfaction pegawai pada Kementerian Ketenagakerjaan dengan Leader Member Exchange (LMX) sebagai variabel pemediasi. Berdasarkan gambar 4. Variabel Self Efficacy pemimpin perempuan (X1) memiliki pengaruh terhadap variabel Job Satisfaction pegawai (Y) pada Kementerian Ketenagakerjaan dengan Leader Member Exchange (LMX) sebagai variabel pemediasi.Variabel LMX sebagai variabel pemediasi pada hipotesis keempat adalah full mediated.Berdasarkan hasiltersebut dapat disimpulkan bahwa hipotesis keempat diterima yaitu Self Efficacy pemimpin perempuan memiliki pengaruh positif terhadap Job satisfaction pegawai pada Kementerian Ketenagakerjaan dengan Leader Member Exchange (LMX) sebagai variabel pemediasi.

\section{Pengujian Hipotesis 5 (H5)}

Hipotesis 5 (H5) : Emotional Intelligence pemimpin perempuan memiliki pengaruh positif terhadap Job Satisfaction Pegawai pada Kementerian Ketenagakerjaan dengan Leader Member Exchange (LMX) sebagai variabel pemediasi. Berdasarkan gambar 4. Variabel Emotional Intelligence pemimpin perempuan (X2) memiliki pengaruh terhadap variabel Job Satisfaction pegawai (Y) dan juga variabel Leader Member Exchange (z) memiliki pengaruh signifikan terhadap Job Satisfaction pegawai (Y). Sehingga mengindikasikan bahwa Emotional Intelligence pemimpin perempuan memiliki pengaruh positif terhadap Job satisfaction pegawai pada Kementerian Ketenagakerjaan dengan Leader Member Exchange (LMX) sebagai variabel pemediasi. Variabel LMX sebagai variabel pemediasi pada hipotesis kelima adalah fully mediated. Berdasarkan hasil tersebut dapat disimpulkan bahwa hipotesis kelima diterima yaitu Emotional Intelligence pemimpin perempuan memiliki pengaruh positif terhadap Job Satisfaction Pegawai pada Kementerian Ketenagakerjaan dengan Leader Member Exchange (LMX) sebagai variabel pemediasi.

\section{Pembahasan \\ Pengaruh Self Efficacy Pemimpin Perempuan terhadap Leader Member Exchange (LMX) pada Kementerian Ketenagakerjaan RI}

Berdasarkan hasil pengujian hipotesis pertama dapat disimpulkan bahwa Self Efficacy Pemimpin Perempuan memiliki pengaruh positif terhadap Leader Member Exchange (LMX) pada Kementerian Ketenagakerjaan RI. Hal ini sesuai dengan hipotesis pada penelitian terdahulu yang dilakukan oleh Dr. Manvinder Singh Tandon Director \& Professor, RIMT/ Institute of Management \& Computer Technology, Mandigobindgarh, Sirhind, Punjab, India Owais Ahmed Ph. D. Scholar, Punjab Technical 
University, Jalander, Punjab, India tahun 2015 yang menyatakan bahwa self efficacy memiliki pengaruh terhadap leader member exchange (LMX). Bandura mendefinisikan self efficacy sebagai keyakinan seseorang terhadap kapabilitas yang dimilikinya dalam mengorganisir dan melaksanakan kegiatan-kegiatan yang mensyaratkan pencapaian tingkat kinerja tertentu. Keyakinan akan kemampuan diri mempengaruhi cara orang dalam berfikir, merasakan dan memotivasi diri mereka sendiri dan dalambertindak. Dengan demikian self efficacy diindikasikan mempunyai pengaruh terhadap hubungan perilaku dalam organisasi antara pemimpin dan bawahan. Pemimpin perempuan dengan self efficacy yang tinggi dapat menciptakan iklim kualitas hubungan yang baik antara pemimpin dan bawahan di Kementerian Ketenagakerjaan Republik Indonesia.

\section{Pengaruh Leader Member Exchange (LMX) terhadap Job Satisfaction pegawai pada Kementerian Ketenagakerjaan RI.}

Berdasarkan hasil pengujian hipotesis kedua dapat disimpulkan bahwa Leader Member Exchange (LMX) memiliki pengaruh positif terhadap Job Satisfaction pegawaipada Kementerian Ketenagakerjaan RI. Hal ini sesuai dengan hipotesis pada penelitian terdahulu yang dilakukan oleh Novebry C Wibowo dan Eddy M Sutanto, 2013 yang menyatakan bahwa Leader Member Exchange ( LMX) memiliki pengaruh positif terhadap Job Satisfaction pegawai. Berdasarkan Teori LMX dari Graen dan Cashman yang menyatakan bahwa dasar untuk membuat hubungan pertukaran tinggi adalah pengendalian pemimpin atas hasil yang diinginkan bawahan. Hasil yang diinginkan ini meliputi pemberian tugas yang menarik dan menyenangkan, pendekegasian tanggungjawab dan otoritas yang lebih besar, informasi yang lebih banyak disampaikan, partisipasi untuk membuat sebagian keputusan pemimpin, penghargaan yang nyata seperti kenaikan gaji, tunjangan khusus seperti jadwal kerja yang lebih baik dan lingkungan kerja yang menyenangkan, dukungan persetujuan pribadi serta kemudahan karir bawahan seperti merekomendasikan untuk promosi, memberikan tugas pengembangan dengan visibilitas yang tinggi. Hal-hal tersebut sangat erat kaitannya dengan kepuasan kerja pegawai. Sehingga sesuai hasil hipotesis ketiga yang menyatakan bahwa leader member exchange memiliki pengaruh yang signifikan terhadap job satisfaction pegawai.

\section{Pengaruh Emotional Intelligence Pemimpin Perempuan terhadap Leader Member Exchange ( $L M X)$ pada Kementerian Ketenagakerjaan RI.}

Berdasarkan hasil pengujian hipotesis ketiga dapat disimpulkan bahwa Emotional IntelligencePemimpin Perempuan memiliki pengaruh positif terhadap Leader Member Exchange ( $L M X)$ pada Kementerian Ketenagakerjaan RI. Hal ini sesuai dengan hipotesis pada penelitian terdahulu yang dilakukan oleh Michael J. Newcombe, UQ Business School; Neal M. Ashkanasy, The University of Queensland, Brisbane, Qld 4072, Australia (2002) yang menyatakan bahwa Emotional Intelligencememiliki pengaruh terhadap Leader Member Exchange (LMX).Sesuai dengan model siklus hidup dalam teori LMX yang memiliki 3 kemungkinan tahapan Graen dan Scandura (1987); Graen \& Uhl-Bien (1991). Hubungan itu dimulai dengan tahap pengujian awal dimana pemimpin dan bawaha mengevaluasi motivasi, sikap dan sumber daya potensial yang akan dipertukarkan. Unsur evaluasi antara pemimpin bawahan adalah hal-hal yang tercantum dalam dimensi emotional intelligence sehingga emotional intelligence tentunya akan memiliki pengaruh terhadap hubungan pertukaran antara pemimpin dan bawahan atau yang lebih dikenal dengan istilah leader member exchange (LMX). Dengan demikian hipotesis keempat diterima dan diindikasikan bahwa Emotional Intellignece pemimpin perempuan memiliki pengaruh positif terhadap Leader Member Exchange (LMX) pada Kementerian Ketenagakerjaan RI. 


\section{Pengaruh Self Efficacy Pemimpin Perempuan terhadap Job Satisfaction pegawai pada Kementerian Ketenagakerjaan RI dengan Leader Member Exchange (LMX) sebagai variable pemediasi}

Berdasarkan hasil pengujian hipotesis keempat dapat disimpulkan bahwa Self Efficacy pemimpin perempuan memiliki pengaruh positif terhadap Job satisfaction pegawai pada Kementerian Ketenagakerjaan dengan Leader Member Exchange (LMX) sebagai variabel pemediasi. Variabel Self Efficacy pemimpin perempuan (X1) tidak memiliki pengaruh terhadap variabel Job Satisfaction pegawai (Y) sehingga dianggap self efficacy pemimpin perempuan tidak memiliki pengaruh secara langsung terhadap job satisfaction. Tetapi pada hipotesis kedua menyatakan bahwa variabel Leader Member Exchange (z) memiliki pengaruh signifikan terhadapJob Satisfaction pegawai (Y). Hal ini mengindikasikan bahwa Self Efficacy pemimpin perempuan dapat memiliki pengaruh positif terhadap Job satisfaction pegawai pada Kementerian Ketenagakerjaan dengan Leader Member Exchange (LMX) sebagai variabel pemediasi (fully mediated). Hal ini sesuai dengan beberapa penelitian terkait dengan variabel LMX sebagai variabel pemediasi seperti penelitian yang dilakukan oleh Onne Janssen, Nico W Van Yperen, University of Groningen tahun 2004.

\section{Pengaruh Emotional Intelligence Pemimpin Perempuan terhadap Job Satisfaction pegawai pada Kementerian Ketenagakerjaan RI dengan Leader Member Exchange (LMX) sebagai variable pemediasi}

Berdasarkan hasil pengujian hipotesis kelima dapat disimpulkan bahwa Emotional Intelligence Pemimpin Perempuan terhadap Job Satisfaction pegawai pada Kementerian Ketenagakerjaan RI dengan Leader Member Exchange (LMX) sebagai variabel pemediasi. Hal ini sesuai dengan penelitian terdahulu yang dilakukan oleh Fong Siu Ping; Ho Ka Yue; Human Resources Management Major tahun 2010 dengan hasil penelitian menunjukkan bahwa ada efek mediasi LMX pada hubungan antara EI dan kepuasan kerja, sedangkan ada efek mediasi TMX pada hubungan antara EI dan kepuasan kerja serta EI dan kinerja pekerjaan. Namun, tidak ada efek mediasi LMX ditemukan pada hubungan antara EI dan kinerja pekerjaan. Meskipun ada banyak penelitian yang menunjukkan ada hubungan yang signifikan antara EI, kepuasan kerja dan kinerja pekerjaan (Abraham, 1999; Cooper \& Sawaf, 1997; Mayer \& Salovey, 1997), jarang ada penelitian sebelumnya yang menyelidiki efek mediasi baik LMX atau TMX pada hubungan antara EI dan kepuasan kerja atau EI dan kinerja pekerjaan. Disarankan untuk melakukan penelitian lebih lanjut untuk mereplikasi dan mengklarifikasi hasil. Hal ini mengindikasikan bahwa Emotional Intelligence pemimpin perempuan dapat memiliki pengaruh positif terhadap Job satisfaction pegawai pada Kementerian Ketenagakerjaan dengan Leader Member Exchange (LMX) sebagai variabel pemediasi.

\section{KESIMPULAN}

Dalam penelitian ini memiliki 5 (lima) hipotesis dengan seluruh hasil hipotesis diterima karena memiliki pengaruh yang signifikan. Hasil penelitian menunjukkan bahwa Self Efficacy dan Emotional Intelligence Pemimpin Perempuan memiliki pengaruh positif terhadap Job Satisfaction pegawai Kementerian Ketenagakerjaan dengan Leader Member Exchange sebagai variabel pemediasi. Pengaruh Self Efficacy pemimpin perempuan terhadap Leader Member Exchange (LMX) dipengaruhi dari magnitude, generality, dan strength. Magnitude dengan indikator berfokus pada tingkat kesulitan tugas yang dihadapi; Generality dengan indikator Kuatnya keyakinan seseorang mengenai kemampuan yang dimiliki; dan Strength dengan indikator Perasaan kemampuan yang ditunjukkan individu pada konteks tugas yang berbeda-beda, baik itu melalui tingkah laku, kognitif dan afektifnya (Gufron dan Rinaswati, 2010). Sedangkan Emotional Intelligence pemimpin perempuan memiliki indikator yang mempengaruhi yang mempengaruhi Leader Member Exchange (LMX) yaitu Self Awareness; Self Motivation, dan Emphaty. Variabel Leader Member Exchange (LMX) yang 
memiliki pengaruh terhadap Job Satisfaction Pegawai dipengaruhi oleh indikator Afeksi, Loyalitas, Kontribusi dan Penghormatan Profesional antara Pemimpin dan Bawahan Langsung (atasan dan bawahan). Dan untuk variabel Job Satisfaction yang dipengaruhi dilihat dari indikator promosi, kompensasi dan lingkungan kerja.

Hasil penelitian dalam tesis ini dilakukan sesuai dengan tahapan-tahapan dalam penelitian serta analisis dan pengolahan data yang sesuai serta mengacu kepada beberapa penelitian terdahulu, sehingga hasil dari penelitian ini dari 5 (lima) hipotesis yang ada memperoleh hasil yang signifikan. Meskipun peneliti telah berusaha merancang dan mengembangkan penelitian ini, namun masih terdapat beberapa keterbatasan dalam penelitian yang perlu dilakukan perbaikan pada penelitian selanjutnya, antara lain : (1) Masih ada unit satuan kerja Eselon I yang tidak menjadi sampel dalam penelitian ini dikarenakan ketidakmerataan penyebaran/distribusi kuesioner sehingga penelitian ini belum dilakukan secara menyeluruh dalam satuan kerja Eselon I; (2) Penelitian ini hanya melibatkan 1(satu) unit pelaksana teknis pusat Kementerian Ketenagakerjaan yang berada di wilayah jabodetabek, sementara masih banyak UPTP yang tersebar di seluruh Indonesia dari Aceh sampai dengan Sorong; (3) Responden dalam penelitian ini masih terbatas pada staf/bawahan dalam pengisian kuesioner akan lebih baik apabila data juga diperoleh dari para pemimpin perempuan. Berdasarkan hasil penelitian yang telah dilakukan terdapat beberapa saran yang dapat dipertimbangkan untuk penelitian selanjutnya, antara lain: (1) Penelitian selanjutnya diharapkan dapat dilakukan pada seluruh unit satuan kerja yang ada pada Kementerian Ketenagakerjaan Republik Indonesia sehingga hasil penelitian dapat digambarkan secara keseluruhan; (2) Penelitian selanjutnya diharapkan dapat dilakukan pada pemerintahan selain Kementerian Ketenagakerjaan Republik Indonesia sehingga dapat diketahui perbandingan untuk sektor pemerintahan; (3) Penelitian selanjutnya diharapkan dapat dilakukan dengan mengembangkan model penelitian sehingga hasil penelitian dapat lebih memberi gambaran yang lebih baik.

\section{DAFTAR PUSTAKA}

Afid Burhanudin, 2014. Teori-teori Kepemimpinan. Diakses pada tanggal 15 Februari 2019 pada https://afidburhanuddin.wordpress.com/2014/01/09/teori-teori-kepemimpinankependidikan/

Aretha Aprilia. 2018. Women@Work.. Jakarta: PT. Gramedia Pustaka Utama

Astrid Indi Dwisty Anwar, 2009. Hubungan antara Self Efficacy dengan Kecemasan Berbicara di Depan Umum, Fakultas Psikologi Universitas, Medan, Sumatera Utara.

Aynul, 2009. Definisi Kepemimpinan. Diakses pada tanggal 5 Februari 2019 dari http://referensikepemimpinan.blogspot.com/2009/03/definisi-pemimpin.html

Bandura, A., 2001. Social cognitive theory: An agentic perspective. Annual review of psychology, Vol. 52, hh. 1-26.

Bangun, Wilson. 2012. Manajemen Sumber Daya Manusia. Erlangga, Jakarta.

Caesar Douglas, 2012. The Moderating Role of Leader and Follower Sex in Dyads on The Leadership Behavior-Leader Effectiveness Realtionships. The Leadership Quarterly Journal, nomor. 23, hh. 163-175.

Caplan, P.,1987. Cultural Construction of Sexuality. London: Tavistock publication 
Chester Schriesm. Linda L. Neider, Terri A. Scandura, 1998. Delegation and Leader Member Exchange: Main Effects, Moderators, and Measurements issues. Academy of Management Journal, Vol 41 No.3, hh. 298-318.

Claartje J. Vinkenburg, Marloes L. van Engen, Alice H. Eagly, \& Mary C. Johannesen-Schmidt, 2011. An exploration of stereotypical beliefs about leadership styles: Is transformational leadership a route to women's promotion? the leadership quarterly journal, vol.22, hh 1021.

Crystal L. Hoyt, Stefanie Simon, Lindsey Reid, 2009. Choosing the best (wo)man for the job: The effects of mortality salience, sex, and gender stereotypes on leader evaluations, the leadership quarterly journal, vol.20, hh 233-246

Dansereau, Graen and Haga (1975), Graen and Cashman (1975) Leader Member Exchange Theory. Diakses pada tanggal 8 Februari 2019, dari http://changingminds.org/explanations/theories/leader member exchange.html

Dennis Reynold PhD, 2002. The Moderating Effect of Leader Member Exchange in the Relationship Between Self Efficacy and Performance. Journal of Human Resources in Hospitality \& Tourism.

Edy Sutrisno, 2014. Manajemen Sumber Daya Manusia. Cetak Ke Enam. Pranada Media Group, Jakarta.

Erin Anggraeni Wijayanto dan Ec. Eddy M. Sutanto,2013. Pengaruh Leader Member Exchange terhadap Kepuasan Kerja, Motivasi Kerja dan Komitmen Organisasional Karyawan Departemen Penjualan pada PT X, AGORA Vol. 1 No.1.

Feist, J \& Feist, G. J., 2010. Teori Kepribadian, edisi 7. Salemba Humanika. Jakarta

Fery Roen, 2013. Teori Kepemimpinan Situasional. Diakses pada tanggal 5 Februari 2019 dari http://perilakuorganisasi.com/teori-kepemimpinan-situasional.html

Fong Siu Ping, Ho Ka Yue, 2010. The Mediating Effects of Leader Member Exchange (LMX) and TeamMember Exchange (TMX) on The Relationship Between Emotional Intelligence, Job Satisfaction and Job Performance of Employees. An Honours Degree Project Submitted to the school of business in partial fulfilment of the graduation for the degree of bachelor of business administration (honours).

Gary Yukl, 2017. Kepeimpinan dalam Organisasi. Edisi Ketujuh. Indeks, Jakarta

George R. Terry,2000. Prinsip-Prinsip Manajemen. (edisi bahasa Indonesia). PT. Bumi Aksara, Bandung.

Goleman Daniel. 1994. Emotional Intelligence.Gramedia Utama, Jakarta.

Graen, G. B., \& Scandura, T. A., 1987. Toward a psychology of dyadic organizing. Research in organizational behavior. Diakses pada January 21, 2016, dari http://psycnet.apa.org,175208.

Handoko, Hani T. 1992. Manajemen Personalia dan SDM.BPFE. Jakarta.

Hemphill, J.K. \& Coons, A.E. 1995. Development of The Leader Behavior Description Questionare. In R.M. Stogdill \& A.E. Coons (Eds), Leader Behavior: Its Description and Measurement. Columbus, Bureau of Business Research, Ohio State University 
Iptek, 2013. Studi Ilmiah Pendukung Mitos Gender. Diakses pada tanggal 15 Oktober 2018 dari https://www.dw.com/id/studi-ilmiah-pendukung-mitos-gender/a-17270987

Karen Milner, Lesley-Anne Katz, Velerie Notrica, 2007. Gender and the quality of the leader-member exchange: findings from a South African organization. South Africa Journal of Phsychology, 37 (2), hh.316-329

Kartini dan Kartono.1994. Pemimpin dan Kepemimpinan. Jakarta : PT. Raja Grafindo Persada.

Kinicki, Angelo dan Brian K. William, 2003, Management (A Practical Introduction), Mc Graw Hill, New York

L. Richard, Hunghes, C.Robert, Ginnett, J.Gordon, Curphy, 2012. Leadership memperkaya pelajaran dari pengalaman. Salemba Humanika.Jakarta.

Leonard K. 2002. Leader Member Exchange Theory. Retrived Juni 16, 2011

Lindsey, Linda L. Gender Roles; A Sociological Perspective. 2011. Pearson/Prentice Hall. Boston.

Linn Van Dyne, Jeffrey Joireman, Dishan Kamdar, 2008. In-Role Perceptions Buffer the Negative Impact of Low LMX on Helping and Enhance the Positive Impact of High LMX on Voice. the leadership quarterly journal, vol 93, no. 6, hh 1195-1207.

Lips, Hillary M., 2007. Sex \& Gender: An Introduction, (New York:McGraw-Hill Higher Education,)

Manvinder Singh Tandon, Mandi Gobin garh, Sirhind, Punjab, 2015. Trust and self-efficacy: interlink between LMX and service performance. The international Journal of Business \& Management (ISSN 232-8916).

Martha Hadiani Anggraita, 2016. Analisis Pengaruh Self Efficacy, Locus of Control dan Conscientiousness terhadap job satisfaction dengan goal commitment sebagai variabel pemediasi. Riset manajemen dan akuntansi volume 7 nomor 1.

Michael J. Newcombe, Neal M. Ashkanasy, 2002. The Role of Affect and Affective congruence in perceptions of Leaders : An Experimental Study. The leadership quarterly journal, vol 13, hh 601-614.

Modern Dictionary of Sociology, 1996, Theodorson George A., 1996

Morrow, P.C. et al., 2005. The role of leader-member exchange in high turnover work environments. Journal of Managerial Psychology, Vol. 20. No. 8, hh. 681 - 694.

N. Sembiring, 2019. Pengertian Pemimpin dna Kepemimpinan menurut Para Ahli. Diakses pada tanggal $\quad 8 \quad$ Februari 2019 dari https://www.academia.edu/15217387/PENGERTIAN PEMIMPIN DAN KEPEMIMPINAN MENURUT PARA AHLI

Novebry C wibowo dan Eddy M Sutanto, 2013. Pengaruh Kualitas Leader Member Exchange (LMX) terhadap produktivitas kerja melalui kepuasan kerja dan komitmen organisasional pada PT. Nutrifood Surabaya, AGORA Vol. 1 No.1.

Oakley, Ann. 1972. Sex, Gender, and Society. Yale University Press, New York

Onne Janssen, Nico W Van Yperen, 2004. Employee's goal orientation, the quality of leader member exchange, and the outcomes of job performance and job satisfaction. Academy of Management Journal, Vol 47 No.3. hh 368-384 
Organ, D. W., 1998. Organizational Citizenship Behavior: The good solder syndrome. Lexington, MA: Lexington Books

Paulus Insap Santosa, 2018. Metode Penelitian Kuantitatif: Pengembangan Hipotesis dan Pengujiannya menggunakan SmartPLS. ANDI, Yogyakarta.

Portal Informasi Indonesia, 2017. Kementerian Ketenagakerjaan RI. Diakses pada tanggal 15 Oktober 2018 dari https://indonesia.go.id/kementerian-lembaga/kementerianketenagakerjaan-republik-indonesia

Putu Eka Purnama Dewi, I Gusti Ayu Manuati Dewi, 2015. Pengaruh Self Efficacy dan Motivasi Kerja terhadap Kepuasan Kerja Karyawan Happy Bali Tour ( Travel Denpasar. Jurnal Manajemen, Strategi Bisnis dan Kewirausahaan Vol. 9. No.1.

Rivai V, Mulyadi D. 2011. Kepemimpinan dan perilaku organisasi. Rajawali pers, Jakarta

Ronit Kark, Ronit Waismel-Manor, \&Boas Shamir, 2012. Does valuing androgyny and femininity lead to a femaleDoes valuing androgyny and femininitylead to a female advantage? The relationship between gender-role, transformational leadership and identification. the leadership quarterly journal, vol 23, hh 620-640

Sedarmayanti, 2011. Manajemen Sumber Daya Manusia dan Produktifitas Kerja. Bandung : Mandar Maju.

Siagian, 2013, Manajemen Sumber daya Manusia. Jakarta : Bumi aksara.

Stephen. P. Robbins, 2005, Perilaku Organisasi (jilid 1 \& 2) edisi delapan.

Sudaryono, 2017. Metodologi Penelitian. PT. Rajagrafindo Persada, Depok.

Sutarto, 1991. Dasar-dasar Kepemimpinan Administrasi. Gadjah Mada University Press, Yogyakarta

Terry, George R., 1972. Principles of Management. Edisi ke-6. Illnois: Richard D. Irwin Homewood.

Truckenbrodt, Y.B., 2000. The Relationship Between Leader-Member Exchange and Commitment and Organizational Citizenship Behavior. Journal of Acquisition Review Quarterly - Summer. hh. 233-244

Veithzal Rivai, 2004.Manajemen Sumber Daya Manusia untuk Perusahaan. Cetakan Pertama. Pt. Raja Grafindo Persa da, Jakarta

Wall Street Journal, 2016. How Men \& Women See the Workplace Differently, http://graphics.wsj.com/how-men-and-women-see-the-workplace-differently/ (diakses 15 Februari 2019).

Wexley, Kenneth, N danYukl, Gary, terjemahan Muh Shobaruddin, 2003. Perilaku Organisasi dan Psikologi Personalia. Rineka Cipta, Jakarta.

Wijaya, K, Phillips, M \& Syarif, H 2002, 'Pemilihan sistem penyimpanan data skala besar', Jurnal Informatika Indonesia, vol. 1, no. 3, hh. 132-140

Wilson, H.T., 1989.Sex and Gender: making cultural sense of civilization.

Zainuddin, 2006. Sosilogi Hukum.Sinar Grafika, Jakarta. 